\title{
CIVIL SOCIETY STRATEGIES AND PROJECTS IN FLOOD HIT AREA: A CASE OF PAKISTAN FLOOD AFFECTED AREAS
}

\author{
Jamshid Ali Turi1,*, Hassan Basheer ${ }^{2}$, Shahryar Sorooshian ${ }^{1}$ and Sadia Shaikh ${ }^{3}$ \\ ${ }^{1}$ Faculty of Industrial Management, Universiti Malaysia Pahang, Malaysia \\ 2Shaheed Zulfiqar Ali Bhutto Institute of Management Sciences (SZABIST), Pakistan \\ ${ }^{3}$ Greenwich University, Karachi, Pakistan
}

\begin{abstract}
In the past few decades, the frequency of floods has increased in Pakistan. Climate change and poor policy making and management system across the country is the main reason of the increasing floods in Pakistan. However, the role and potential of Civil Society has not been acknowledged by different stakeholders in disaster management. The aim of the study to explore the role of civil societies contribute in the flood affected area also how their efforts can be more meaningful for the flood affected communities. A quantitative study based on questionnaire conducted in village Ghangwal. The study reveals that Civil Societies responses are quicker than the government response to the flood affected areas. The major role of Civil Society is in rescue and recovery phases. However, in mitigation and rehabilitation phases the role is limited. Government can reduce the risks of floods if Local Government system and coordinated efforts at all level are ensured. In the conclusion, study identified four major areas where Civil Societies support the affected communities are civil society's response is quicker and more immediate; rescue the affected people and nature of help extended by the civil societies; basic needs of the affected people so need based assessment was carried out to compensate and rehabilitate the prospective flood victims. Lastly the study discovered the methods of distribution of relief-goods among the victims.
\end{abstract}

ARTICLE HISTORY

Received: $16-09-2018$

Accepted: $29-11-2018$

\section{KEYWORDS}

Civil society; Flood, Disaster management, NDMA, World Bank

\section{INTRODUCTION}

Pakistan is listed on 7th among climate change risk (CCR) and has suffered with extreme weather in the past and continuously suffering with catastrophic events (Kreft et al., 2016). For decades, Pakistan has witnessed some serious and catastrophic events among flood more commonly hit the country. The frequency of these disasters has slowed down the pace of socio-economic development of the country.

The scientists warn that the number of different disasters is likely to increase in the future as the climate change will increase the frequency and intensity of different disasters in Pakistan (UNDP, 2016). Pakistan is not the only expected and effected, but developed countries like USA are also being hit by some cyclones. East coast of Malaysia is also hit by the flood every single year from decades. Pakistan is a disaster-prone country which faces diverse disaster. However, the flood is the major disaster which Pakistan has faced in recent years and likely to bear this very disaster more frequently in the future because of global warming and climate change. Therefore, Pakistan has established National Disaster Management Authority (NDMA) and Earthquake Reconstruction and Rehabilitation Authority (ERRA) to counter catastrophic events in the country.

Disaster is an over-whelming situation where local population becomes helpless. As a result, other stake-holders come to the help of the affected community. These actors include the government institutions, local community, national community, international community, affected population and Civil Society. These are the major actors and factors which play their role to counter disasters. Presently, the role of Civil Society is being recognized and acknowledged globally. Therefore, the Civil Society role becomes very important to counter disasters. Specially, in case of floods, Civil Society and other NGOs come up to help the victims of the floods. In case of Pakistan, the role of Civil Society has not been recognized and acknowledged yet.

Floods have been creating disaster in Pakistan for a long time. The governments alone were unable to cope with the emergency. Therefore, the Civil Society and international community reach the area to help the victims. These efforts are often unorganized and not coordinated well with the government institutions and among other stake holders. Furthermore, these efforts and services have not been acknowledged by different stakeholders in disaster management (UNDP, 2016; Careem, 2016). So, there is a need to know the pattern and nature of their help and identifying gaps in coordination among different stake-holders. 
The objective is to explore the role of "Civil Societies" helps the affected people in flood hit areas and how these efforts can be more useful for the flood affected communities. This study will be useful for Policy Makers, Practitioners, NGOs, Civil Society and all other stake holders working in disaster management field. Research questions include:

How does Civil Society respond, when the flood hits the area?

What is the nature of help by Civil Society?

What is needed during floods?

What are the distribution methods of relief goods?

\section{LITERATURE REVIEW}

The world has faced a significant social, environmental and economic transformation in previous decades due to disaster and floods, which brought both negative as well as positive impacts. Sometimes it leads to growth, sustainability and development (Faulkner, 2001; UNDP, 2005). However, most of the time it causes disruption and destabilization in the socio-environmental systems reflects the negative impacts. Sometimes, it takes hardly minutes to destroy cities and countries (Mete \& Zabinsky, 2010). The future major challenge is the climate change and Pakistan are among most vulnerable nations who are likely to face disasters. One major cause of flood devastation is demographic changes (Hussain \& Junaid, 2013). Population and the proportion of people living in flood-prone river basins have increased by $114 \%$. Besides, the people who are living on cyclone-exposed coastlines have increased by $192 \%$. Presently, more than half of the world's large cities, with populations ranging from 2 to 15 million, are situated in areas of high earthquake risk (Mansourian, Rajabifard, Zoeja, \& Williamson, 2006).

Rapid urbanization will increase exposure to natural hazards. With the passage of time world is becoming a global village, people around the globe are interacting and communicating with each other at the faster speed (Moe \& Pathranarakul, 2006). Similarly, Civil Society is gaining strength and resources while empowering each other. The better connectivity and communication have rendered the Civil Society role and scope more vibrant and wider. As a result, the potential contribution of the Civil Society cannot be overlooked (NezihAltay \& Green, 2006; Moe \& Pathranarakul, 2006). The pool of resources and better coordination with government institutions can create a visible difference in the society. In Pakistan also, has faced several disasters in the last two decades. The civil Society has been contributing in disaster management for all these years in diverse domain and nature. Therefore, it becomes incubate to see the role, project and contribution is of the civil society to be proactive for the future to face the challenges and hazards of the floods and disaster in an effective and efficient way (Himayatullah \& Abuturab, 2017; RehmanTariq \& Giesen, 2012). In the contemporary world Civil Society has achieved a significant role in shaping and formulating the societies. Several sociopolitical movements have transformed the world recently. The Egypt is a case in point in this regard. The influence of Civil Society in every sphere is gaining momentum. Therefore, the maximum utilization of Civil Society potential can minimize the damage and alleviate the pain suffered by disaster victims (Malik \& H, 2016; Hussain \& Junaid, 2013).

Hazards convert into a disaster through a societal process (Careem, 2016). In the World Conference on Disaster Reduction (2005) in Japan, a joint framework for actions for disaster risk reduction by 2015 was formulated and agreed upon, which is called Hyogo Framework for Action 2005-2015 (Moore, 2005). They focused on building on the Resilience of Nations and Communities to Disasters.

Strengthen disaster preparedness for effective response at all levels and to strengthen the capacity of communities to reduce disaster risk at local level. It says that all individuals and communities mobilize local resources to reduce vulnerabilities to hazards (Himayatullah \& Abuturab, 2017). Hoyogo framework for action 2005-15 emphasizes on enhancing the capacity building of the vulnerable communities on regional, national and international level. Therefore, some INGOs are enhancing the capacity building of local level community-based organizations. This initiative is helping the local communities to reduce disasters' risk. As a result, local communities are gaining training and skills to effectively launch a relief and rehabilitation campaign in some countries (Jemes, 2009; Athukorala \& Resosudarmo, 2006).

The established brands often send flood relief goods to the affected people in different parts of the world. They do so as a corporate social responsibility. The association of textile industry in Faisalabad sent two trucks of tents to Hafizabad in 2013 floods (UNDP, 2016; Himayatullah \& Abuturab, 2017). Similarly, Multan commerce and trade sent cash to the flood affected community in Muzaffargarah district. The donors realize that the transition toward democratically elected governments does not guarantee a more democratic culture. This might have led to a more positive approach to the promotion of good governance in the form of support for Civil Society (Tingsanchali, 2012; ZubairAhmed, 2013).

The motive given by donors for supporting Civil Society is essentially that a strong Civil Society will demand a more democratically accountable and transparent state, and this will lead to a sustainable good governance (Vasilescu, Khan, $\&$ Khan, 2008). In all over the world the NGOs often work in collaboration with the government institutions and other stakeholders to manage catastrophic events. When the disaster occurs, measures are taken immediately to counter it.

There are five stages which are required to manage disasters. These phases include prevention, preparedness, emergency response, recovery and mitigation. Some of the renowned development sector experts express that governments are generally wasteful and not trust-worthy (Vasilescu, Khan, \& Khan, 2008; Ainuddin, Aldrich, Routray, ShabanaAinuddin, \& AbidaAchkazai, 2013). Therefore, the role of CSOs has increased manifold these days. The CSOs members belong to diverse walk of lives, they can pressurize the government to perform effectively and with honesty. The role of watchdog makes the Civil Society more important. The primary responsibility to manage disaster lies with the government, however, NGOs and individuals should come forward to support the government as it is, sometimes, no 
longer possible for the governments to manage mass disasters (Ainuddin \& Routray, 2012). In Japan, Turkey and India, the role of Civil Society was not considered so important in disaster management until the major earthquakes of Kobe, Marmara and Gujarat respectively. Earlier, it was assumed that the governance craft is exclusively for the politicians and civil servants. Later this concept was changed ant the Civil Society gained importance. All communities around gather to help the disaster hit area, however, some of the NGOs have designed better projects and delivered very well in some of the disaster hit areas (Trim, 2004; Shaw \& Goda, From Disaster to Sustainable Civil Society: The Kobe Experience, 2004).

For instance, the Christian Aid Initiative identified 5 villages in Kirghizstan to train the locals and local government officials to manage disasters where they established different projects and teams to counter disasters. This agency devised an early warning system as well based on science and local wisdoms (Hussain \& Junaid, 2013). Similarly, in district Chikwawa in southern Malawai people were badly affected by river Mthumba flooding in 2003. There was an unprecedented loss of life, property and other livelihoods. The teachers' organization, along with students started a campaign of plantation on a large scale which reduced the effects of floods in the later years. Likewise, in a small village of Chikalumpha in Nepal, an organization of layers, the Peace Preacher, started Plantation projects to create resistance against the floods which often hit the area (Ainuddin \& Routray, 2012).

The projects were so successful that the neighboring villages also follow the pattern of plantation that flood was no more a disaster after four years (Gruyter, 2011). In Santana village in 2006 an earthen flood dike project was built to protect crops. The labor for this purpose was predominantly provided by a task force which was mainly the composition of church members and local authorities. A new multi-sector approach was adopted to counter floods in the area. An advocacy campaign was launched. They demanded new by-laws for farmers and new ways of plantation were introduced. In Peru the Mestizo communities developed a project to mitigate the losses of floods. The local authorities with Oxfam cooperation launched an extensive civil defense program which turned out to be an amazing protective shield against all disasters in the area (Gruyter, 2011; Stanganelli, 2008). Again, in Peru some schools were identified where students were imparted civil defense training to fight against every kind of disaster. The projects were made part of compulsory part of education in some schools and this was an amazing success. The students were the rapid response force during floods. This task force was passionately involved in protecting their communities from floods. A Community-Based Disaster Risk Management in Indonesia (CBDRM) initiative was launched in 2005 to devise an early warning system to protect the people from floods. This initiative was in collaboration with a local NGO (Adger, Hughes, Folke, Carpenter, \& Rockström, 2005; Jemes, 2009).

They could warn their community well in time to vacate their places. They installed a communication system there which received latest information and data from emergency department. Similarly, they started an advocacy campaign to convince the government to enhance the capacity building of the people to counter floods. They demanded that interest free loans may be sanctioned to the community members. This initiative will help them increase their resilience and decreasing their vulnerability (Djalante, Thomalla, Sabaruddin, \& Carnegie, 2011). When a disaster strikes, several stages of disaster management take place to alleviate the intensity of the pain of the people. The first and immediate step is to provide them with basic needs like rescue, relocation, water, food and shelter etc. Following these actions, the process of recovery begins which needs more coordinated measures (Mateeul Haq, Memon Akhtar Sher, Muhammad Siddiqi, Jillani, \& Rahmatullah, 2012; Careem, 2016). For instance, some of the areas were recovered more quickly than their neighboring ones like half of New Orleans' population recovered more quickly because of Civil Society' active involvement. Similarly, the NGOs volunteers immediately reached the hit area to rescue the people.

After two to four months the NGOs were busy in the long-term rehabilitation programs. The NGOs and Civil Society comes forward to help the victims (Himayatullah \& Abuturab, 2017). Three case studies from India, Turkey and Japan have shown that the governments were failed to manage the disaster but the Civil Society came to help the victims. The IOM has contributed a lot during the floods of 2010 and 2011 in Pakistan (Gruyter, 2011; RehmanTariq \& Giesen, 2012). The organization distributed tents and NFI (non-food items) kits in many floods affected areas of Pakistan. This was a great relief for the people stuck in the floods. Besides, the 'Shelter cluster' effectively designed and established shelter designs and infrastructures in Sindh province for flood affected people in 2011. In District Nawab Shah and Thatha, many people were homeless as it was an unprecedented flood. So, the tents provided to them were a great help and rehabilitation Project initiated by the Shelter Cluster. Similarly, UK based INGO, International Alert, established a five-day camp to increase the capacity of locals to manage floods in five villages in Nowshera district of Pakistan.

An organization of lawyers in District Hafizabad designed a project, collected items from the locality and sent five trucks, loaded with clothes, dry ration and shoes to flood affected area in Tehsil Pindi Bhattian in 2014 flood (Kapucu, 2015). In 2013, an organization of teachers 'Al iLMS' deigned a project to launch a campaign among students to spread awareness to help flood affected in Muzaffargarh district of Pakistan. And it was much successful in getting their targeted objectives (Yusoff \& Khan, 2013; Shaw, Shiwaku, Kobayashi, \& Kobayashi, 2004). Karachi stock exchange started a fund-raising campaign and collected two million rupees for flood victims in Sindh province in 2011. Besides, the organization managed to prepare twenty loaded trucks comprised of food items, medicines, tents and clothes for flood affected in the province (Hussain \& Qasim, 2015). The relief goods were handed over to Pakistan Navy to take this contingent to the affected area. Similarly, during the 2005 floods in district Sargodha, students' wings of some political parties like Jamaat-e-Islami, Pakistan People's Party Parliamentarians, Pakistan Muslim league designed some collaborated projects in the schools, colleges and bazaars to collect money, daily use items and dry ration to distribute them among flood affected people in different villages in the district Sargodha. They managed to prepare ten trucks loaded with diverse relief goods (Hussain \& Junaid, 2013; Hussain \& Qasim, 2015). 


\section{Theoretical Framework}

Disaster Management Cycle theory is the basis of this research study. This theory was introduced in 1920 after a research conducted by Prince (Gruyter, 2011; O'Brien, O'Keefe, Gadema, \& Swords, 2010; Perry, 2003). His study concluded that every disaster management Project consists of four main stages. The framework contains Mitigation, Preparedness, Response and Recovery. This phase brings back the affected community to normal life. In this phase temporary housing, medical care and grants are awarded to rehabilitate the people (Perry, 2003).

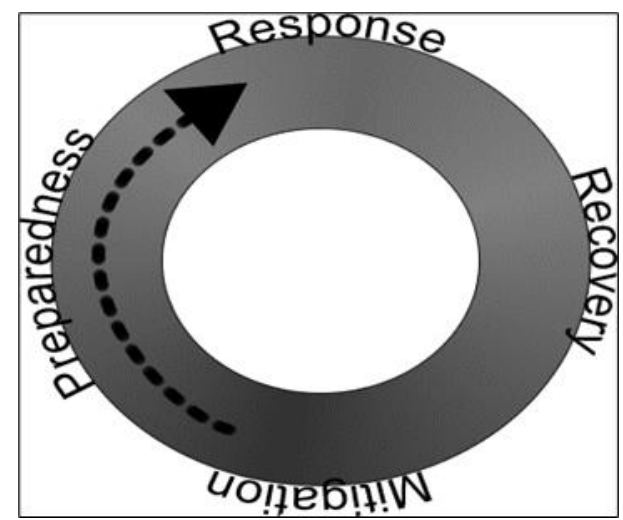

Figure 1: Disaster Management Cycle (Perry, 2003)

\section{Proposed Framework and Research Hypothesis}

When floods hit an area, the inhabitants should rescue themselves and their belongings. If the intensity of the flood is high, the effected ones should flee their houses to save their lives. In the worst hit areas, Civil Society comes forward to rescue them and help the affected population. The self-explanatory diagram has been drawn here to understand the Conceptual Framework for this research study (Obwaya, 2010; Gruyter, 2011). This diagram has also been used by different researchers while focusing the rehabilitation issues in the flood affected areas (Ainuddin \& Routray, 2012; Himayatullah \& Abuturab, 2017).

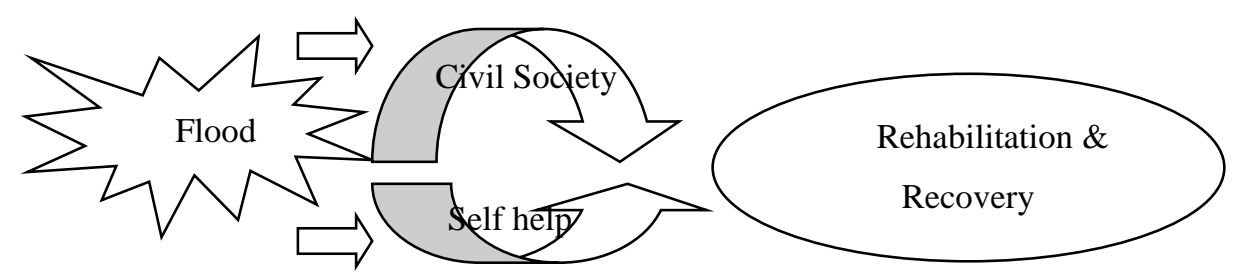

Figure 2: Proposed Framework

\section{METHODOLOGY}

The study was quantitative in nature. Data was collected through survey technique using self-administrated questionnaire selected from (Careem, 2016; RehmanTariq \& Giesen, 2012). The research questionnaire was designed using five points Likert scale [i.e., 1-strongly disagree, 2-disagree, 3-don't know, 4-agree, 5-strongly agree]. A survey was selected for the study because, it is a popular data collection method used in a post-positivism paradigm to collect primary data (Hewege \& Perera, 2013; Williams, 2007). It is mostly used because they provide a quick, inexpensive, and accurate means of assessing information about a population. The use of surveys permits a researcher to study more variables at one time than is typically possible in laboratory or field experiments, whilst data can be collected about real world environments (Ottawa, 2003; Molenberghs, 2015).

The targeted population was the villagers of the targeted research area and the members of the civil society. Convenient sampling method was used to collect data from the targeted population. A convenient sampling technique was adopted on the premise that all selected population and sample worked in the flood effected area or were the inhabitant those areas. The total numbers of respondents in the sample for this research study were 113. SPSS software used to analyse the collected questionnaire data.

\section{FINDINGS}

The findings of the study indicated strong associations between different strategies which were adopted by the representative of the civil society in initiating and designing different rehabilitation projects. Rapid response, nature of help needed by the flood victims, calculation if need based assessment and the method of distribution. The findings are 
illustrated in Table 1 shows majorities of the respondents are happy with rapid response; nature of help; need based assessment and distribution methods. The minimum variation and dispersion are seen in the data which also support the study argument.

Table1: Descriptive statistics

\begin{tabular}{cccccc}
\hline & $\mathbf{N}$ & Minimum & Maximum & Mean & Std. Deviation \\
\hline \hline Rapid response & 113 & 2.25 & 4.00 & 3.5602 & .48922 \\
Nature of help & 113 & 1.67 & 4.00 & 3.2515 & .59933 \\
$\begin{array}{l}\text { Need based } \\
\text { assessment }\end{array}$ & 113 & 1.67 & 4.00 & 3.1917 & .61690 \\
$\begin{array}{c}\text { Distribution Method } \\
\text { Valid N }\end{array}$ & 113 & 2.00 & 4.00 & 3.5457 & .45874 \\
\hline
\end{tabular}

To see the difference and mutuality among the strategies and techniques used by civil society workers, based on their workers (employees) academic qualification ANOVA is used. Results are shown in table 2. A significant difference is found in supporting techniques and projection of the civil workers having different qualifications.

Table.2: ANOVA for qualification

\begin{tabular}{|c|c|c|c|c|c|c|}
\hline & & $\begin{array}{c}\text { Sum of } \\
\text { Squares }\end{array}$ & Df & $\begin{array}{c}\text { Mean } \\
\text { Square }\end{array}$ & $\mathbf{F}$ & Sig. \\
\hline & Between Groups & 4.946 & 1 & 4.946 & 25.372 & .000 \\
\hline \multirow[t]{3}{*}{ Rapid Response } & Within Groups & 20.663 & 106 & .195 & & \\
\hline & Total & 25.609 & 107 & & & \\
\hline & Between Groups & 5.065 & 1 & 5.065 & 16.048 & .000 \\
\hline \multirow[t]{3}{*}{ Nature of Help } & Within Groups & 34.087 & 108 & .316 & & \\
\hline & Total & 39.153 & 109 & & & \\
\hline & Between Groups & 2.722 & 1 & 2.722 & 7.573 & .007 \\
\hline \multirow[t]{3}{*}{$\begin{array}{l}\text { Need based } \\
\text { Assessment }\end{array}$} & Within Groups & 39.901 & 111 & .359 & & \\
\hline & Total & 42.623 & 112 & & & \\
\hline & Between Groups & 2.096 & 1 & 2.096 & 13.435 & .000 \\
\hline \multirow[t]{2}{*}{ Distribution Method } & Within Groups & 17.314 & 111 & .156 & & \\
\hline & Total & 19.409 & 112 & & & \\
\hline
\end{tabular}

Since the difference between the groups is significant as shown in table 2 above, mean comparison in table 3 shows that Rapid response is mostly used by MPhil qualified civil worker $(\mathrm{M}=3.8, \mathrm{~S} . \mathrm{D}=0.20)$ in comparison to Masters $(\mathrm{M}=3.6, \mathrm{~S} . \mathrm{D}=0.46)$ and Bachelor teachers $(\mathrm{M}=3.13$, S.D $=0.49)$ where $\mathrm{M}$ and S.D stands for mean and standard deviation respectively. Civil Workers with higher qualifications adopt best possible, feasible and optimal option for to help the inhabitants and flood victims of the locality, as shown from the values. MPhil degree holders adopted flexible supporting and helping methodologies $(\mathrm{M}=3.61, \mathrm{~S} . \mathrm{D}=0.13)$ as compare to $\mathrm{BS}(\mathrm{M}=3.35, \mathrm{~S} . \mathrm{D}=.51)$ and $\mathrm{Master}(\mathrm{M}=3.2$, $\mathrm{S} . \mathrm{D}=.59$ ) degree holders. It's worth mentioning here that the BS degree holder proved more flexible in selecting better supporting methodology as compared to Master degree holder in our research findings. Similarly, workers with MPhil degree do better need assessment and devised strategies and projects $(M=3.56, \mathrm{~S} . \mathrm{D}=0.5)$ than Master degree $(\mathrm{M}=3.5, \mathrm{~S}$. $\mathrm{D}=0.5)$ and $\mathrm{BS}(\mathrm{M}=2.76, \mathrm{~S} . \mathrm{D}=0.6)$ and $)$ degree holders. Civil worker with MPhil degree $(\mathrm{M}=3.78, \mathrm{~S}$. $\mathrm{D}=.13)$ adopts flexible and easy-to-use distribution strategies in their projects as compared to Masters. 
Table 3: Mean values for qualification

\begin{tabular}{|c|c|c|c|c|c|}
\hline \multicolumn{2}{|c|}{ Qualification } & \multirow{2}{*}{$\begin{array}{c}\begin{array}{c}\text { Rapid } \\
\text { Response }\end{array} \\
3.1346\end{array}$} & \multirow{2}{*}{$\begin{array}{c}\begin{array}{c}\text { Nature of } \\
\text { Help }\end{array} \\
3.3590\end{array}$} & \multirow{2}{*}{$\begin{array}{c}\begin{array}{c}\text { Need based } \\
\text { assessment }\end{array} \\
2.7692\end{array}$} & \multirow{2}{*}{$\begin{array}{c}\begin{array}{c}\text { Distribution } \\
\text { Methods }\end{array} \\
3.5128\end{array}$} \\
\hline & Mean & & & & \\
\hline \multirow[t]{3}{*}{ Bachelor } & $\mathrm{N}$ & 13 & 13 & 13 & 13 \\
\hline & Std. Deviation & .49598 & .51750 & .64384 & .32247 \\
\hline & Mean & 3.6011 & 3.2125 & 3.2589 & 3.5603 \\
\hline \multirow[t]{2}{*}{ Master } & $\mathrm{N}$ & 89 & 91 & 94 & 94 \\
\hline & Std. Deviation & .46880 & .62166 & .59899 & .48690 \\
\hline \multirow[t]{3}{*}{ MPhil } & Mean & 3.8750 & 3.6111 & 3.5556 & 3.7889 \\
\hline & $\mathrm{N}$ & 6 & 6 & 6 & 6 \\
\hline & Std. Deviation & .20917 & .13608 & .53403 & .13608 \\
\hline \multirow[t]{3}{*}{ Total } & Mean & 3.5602 & 3.2515 & 3.1917 & 3.5457 \\
\hline & $\mathrm{N}$ & 108 & 110 & 113 & 113 \\
\hline & Std. Deviation & .48922 & .59933 & .61690 & .45874 \\
\hline
\end{tabular}

To see the difference in supporting techniques used by civil based on professional qualification like Project Management, Engineering Management, and ANOVA is used. Results are shown in table 4 below. A significant difference is found in supporting strategies used by civil workers of different qualifications.

Table 4: Strategies of the civil society

\begin{tabular}{|c|c|c|c|c|c|c|}
\hline & & $\begin{array}{c}\text { Sum of } \\
\text { Squares }\end{array}$ & Df & $\begin{array}{c}\text { Mean } \\
\text { Square }\end{array}$ & $\mathbf{F}$ & Sig. \\
\hline \multirow{3}{*}{ Rapid response } & Between Groups & 3.098 & 2 & 1.549 & 7.226 & .001 \\
\hline & Within Groups & 22.511 & 105 & .214 & & \\
\hline & Total & 25.609 & 107 & & & \\
\hline \multirow{3}{*}{ Nature of help } & Between Groups & 1.065 & 2 & .532 & 1.496 & .029 \\
\hline & Within Groups & 38.088 & 107 & .356 & & \\
\hline & Total & 39.153 & 109 & & & \\
\hline \multirow{3}{*}{ Need based assessment } & Between Groups & 2.856 & 2 & 1.428 & 3.949 & .022 \\
\hline & Within Groups & 39.768 & 110 & .362 & & \\
\hline & Total & 42.623 & 112 & & & \\
\hline \multirow{3}{*}{ Distribution Method } & Between Groups & 1.480 & 2 & .740 & 4.541 & .013 \\
\hline & Within Groups & 17.929 & 110 & .163 & & \\
\hline & Total & 19.409 & 112 & & & \\
\hline
\end{tabular}

Result of Table 4 show difference between the groups is significant. Mean comparison in table 5 shows that civil workers with higher professional qualifications use more rapid responses $(M=3.64, S$. $D=0.31)$ In comparison to nonprofessional qualified workers $(\mathrm{M}=3.56, \mathrm{~S} . \mathrm{D}=.54)$. similarly, professional workers were found more concerned with the need-based assessment strategies in managing and distributing relief goods as shown in the table values $(\mathrm{M}=3.34, \mathrm{~S}$. $\mathrm{D}=.5)$ in comparison $(\mathrm{M}=3.12, \mathrm{~S} . \mathrm{D}=.63)$. Professional workers were also found to be more concerned with the calculation of nature of help needed to the affected, having mean and S.D values $(M=3.6, S . D=.59)$ in comparison to nonprofessional workers $(\mathrm{M}=3.24, \mathrm{~S} . \mathrm{D}=.6)$. But non-professional was using more acceptable language and distribution methods, were more used to the custom and tradition as compared to professional as evident from the values $(\mathrm{M}=3.54, \mathrm{~S}$. $\mathrm{D}=.46)$ in comparison $(\mathrm{M}=3.45, \mathrm{~S}$. $\mathrm{D}=.45)$. 
Table 5: ANNOVA for professional qualifications

\begin{tabular}{|c|c|c|c|c|c|}
\hline \multicolumn{2}{|c|}{$\begin{array}{l}\text { Professional } \\
\text { Qualification } \\
\end{array}$} & \multirow{2}{*}{$\begin{array}{c}\text { Rapid Response } \\
3.5663\end{array}$} & \multirow{2}{*}{$\begin{array}{c}\begin{array}{c}\text { Nature of } \\
\text { Help }\end{array} \\
3.2444\end{array}$} & \multirow{2}{*}{$\begin{array}{c}\begin{array}{c}\text { Need-Based } \\
\text { Assessment }\end{array} \\
3.1239\end{array}$} & \multirow{2}{*}{$\begin{array}{c}\begin{array}{c}\text { Distribution } \\
\text { Method }\end{array} \\
3.5470\end{array}$} \\
\hline & Mean & & & & \\
\hline \multirow{3}{*}{$\begin{array}{l}\text { Professional } \\
\text { Qualification }\end{array}$} & $\mathrm{N}$ & 76 & 75 & 78 & 78 \\
\hline & $\begin{array}{c}\text { Std. } \\
\text { Deviation }\end{array}$ & .54556 & .60611 & .63589 & .46516 \\
\hline & Mean & 3.6406 & 3.3667 & 3.3429 & 3.5429 \\
\hline \multirow{3}{*}{$\begin{array}{l}\text { Professional } \\
\text { qualification }\end{array}$} & $\mathrm{N}$ & 32 & 35 & 35 & 35 \\
\hline & $\begin{array}{c}\text { Std. } \\
\text { Deviation }\end{array}$ & .31068 & .59299 & .55121 & .45075 \\
\hline & Mean & 3.5602 & 3.2515 & 3.1917 & 3.5457 \\
\hline \multirow{2}{*}{ Total } & $\mathrm{N}$ & 108 & 110 & 113 & 113 \\
\hline & $\begin{array}{c}\text { Std. } \\
\text { Deviation }\end{array}$ & .48922 & .59933 & .61690 & .45874 \\
\hline
\end{tabular}

To see the difference in supporting techniques used by civil workers based on Gender, ANOVA is used. Results are shown in table 6 below. There is no significant difference in supporting strategies used by teachers of on the basis except for relationship development. According to the Table 6, there is no significant difference between the supporting strategies, methodologies adopted by male and female. Table 7 also shows that mean values of all the constructs are near to highest values and the Standard deviations of all constructs are smaller, which again support our comments that both male and female use same strategies to support the flood effected area in Pakistan.

Table.6: ANOVA for the responses based on gender

\begin{tabular}{|c|c|c|c|c|c|c|}
\hline & & $\begin{array}{c}\text { Sum of } \\
\text { Squares }\end{array}$ & Df & $\begin{array}{c}\text { Mean } \\
\text { Square }\end{array}$ & $\mathbf{F}$ & Sig. \\
\hline \multirow{3}{*}{ Rapid Response } & Between Groups & .294 & 1 & .294 & 1.232 & .270 \\
\hline & Within Groups & 25.315 & 106 & .239 & & \\
\hline & Total & 25.609 & 107 & & & \\
\hline \multirow{3}{*}{ Nature of Help } & Between Groups & .012 & 1 & .012 & .033 & .857 \\
\hline & Within Groups & 39.141 & 108 & .362 & & \\
\hline & Total & 39.153 & 109 & & & \\
\hline \multirow{3}{*}{$\begin{array}{l}\text { Need Based } \\
\text { Assessment }\end{array}$} & Between Groups & 1.158 & 1 & 1.158 & 3.100 & .081 \\
\hline & Within Groups & 41.465 & 111 & .374 & & \\
\hline & Total & 42.623 & 112 & & & \\
\hline \multirow{3}{*}{$\begin{array}{l}\text { Distribution } \\
\text { Methods }\end{array}$} & Between Groups & .000 & 1 & .000 & .002 & .965 \\
\hline & Within Groups & 23.569 & 111 & .212 & & \\
\hline & Total & 23.569 & 112 & & & \\
\hline
\end{tabular}


Table 7: Mean values for the Gender

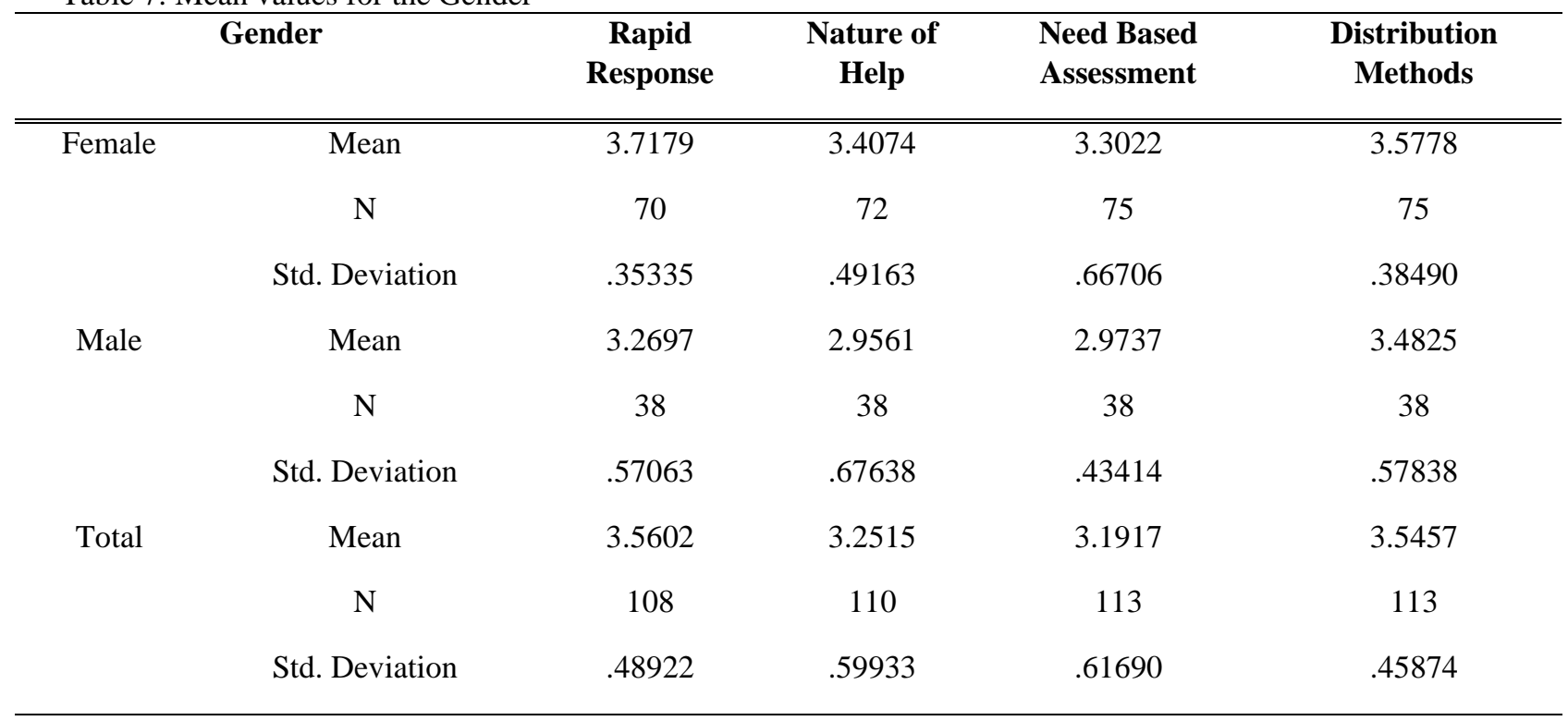

To see the difference in relief response by the Govt: of Pakistan and the Civil Society in the flood affected areas, ANOVA was used. Results are shown in table 8. A significant difference is found in the responses used by the Govt: of Pakistan and the workers of the Civil societies.

Table8: ANNOVA for govt and civil worker responses

\begin{tabular}{|c|c|c|c|c|c|c|}
\hline & & $\begin{array}{c}\text { Sum of } \\
\text { Squares }\end{array}$ & Df & $\begin{array}{c}\text { Mean } \\
\text { Square }\end{array}$ & $\mathbf{F}$ & Sig. \\
\hline \multirow{3}{*}{ Rapid Response } & Between Groups & .294 & 1 & .294 & 1.232 & .007 \\
\hline & Within Groups & 25.315 & 106 & .239 & & \\
\hline & Total & 25.609 & 107 & & & \\
\hline \multirow{3}{*}{ Nature of Help } & Between Groups & .012 & 1 & .012 & .033 & .000 \\
\hline & Within Groups & 39.141 & 108 & .362 & & \\
\hline & Total & 39.153 & 109 & & & \\
\hline \multirow{3}{*}{$\begin{array}{l}\text { Need Based } \\
\text { Assessment }\end{array}$} & Between Groups & 1.158 & 1 & 1.158 & 3.100 & .001 \\
\hline & Within Groups & 41.465 & 111 & .374 & & \\
\hline & Total & 42.623 & 112 & & & \\
\hline \multirow{3}{*}{ Distribution Methods } & Between Groups & .000 & 1 & .000 & .002 & .005 \\
\hline & Within Groups & 23.569 & 111 & .212 & & \\
\hline & Total & 23.569 & 112 & & & \\
\hline
\end{tabular}


Table 9: Response by Civil Society and Govt: of Pakistan

\begin{tabular}{|c|c|c|c|c|c|}
\hline \multicolumn{2}{|c|}{$\begin{array}{l}\text { Professional } \\
\text { Qualification }\end{array}$} & \multirow{2}{*}{$\begin{array}{c}\begin{array}{c}\text { Rapid } \\
\text { Response }\end{array} \\
3.5663\end{array}$} & \multirow{2}{*}{$\begin{array}{c}\begin{array}{c}\text { Nature of } \\
\text { Help }\end{array} \\
3.2444\end{array}$} & \multirow{2}{*}{$\begin{array}{c}\text { Need-Based } \\
\text { Assessment }\end{array}$} & \multirow{2}{*}{$\begin{array}{c}\text { Distribution } \\
\text { Method }\end{array}$} \\
\hline & Mean & & & & \\
\hline & $\mathrm{N}$ & 76 & 75 & 78 & 78 \\
\hline 10 sponise & Std. Deviation & .54556 & .60611 & .63589 & .40516 \\
\hline \multirow{3}{*}{$\begin{array}{c}\text { Govt: } \\
\text { Response }\end{array}$} & Mean & 3.6406 & 3.3667 & 3.3429 & 3.4429 \\
\hline & $\mathrm{N}$ & 32 & 35 & 35 & 35 \\
\hline & Std. Deviation & .31068 & .59299 & .55121 & .40075 \\
\hline \multirow{3}{*}{ Total } & Mean & 3.5602 & 3.2515 & 3.1917 & 3.5457 \\
\hline & $\mathrm{N}$ & 108 & 110 & 113 & 113 \\
\hline & Std. Deviation & .48922 & .59933 & .61690 & .65874 \\
\hline
\end{tabular}

\section{CONCLUSIONS AND FUTURE RECOMMENDATIONS}

Civil Society is becoming very vibrant and active throughout the world. There is a dire need for the policy makers and officials to promote their services, for the cause of humanity, rehabilitation and earlier recovery. Same is the case with the Pakistan. In some previous disasters, Civil Society was very active. They were part of rescue, recovery and rehabilitation process in their individual capacity. In this way they were certainly creating an impact and contributing a lot. However, there is an urgent need of coordinated efforts to counter disasters. The government should devise a policy and platform to pool resources and expertise to manage every disaster. Coordinated efforts can reduce the workload and enhance the output with fewer resources. Otherwise, there will be duplication of work and waste of time and resources. The Civil Society has a great potential to help disaster victims. There is an urgent need of coordinated efforts of all stakeholders in the country.

\section{Practical Implications}

The study concludes that local government system should be resumed. As the disasters are a local phenomenon, local communities must be taken onboard to initiate any measure regarding disaster prone community. Government should revise the National Disaster Management Policy to focus on coordinated and integrated management system of disaster risk reduction where Civil Society should be the major focus. Disaster management course should be included in the course curriculum in schools and colleges. Media and disaster management bodies should be made more effective and research-oriented.

\section{REFERENCES}

Adger, W. N., Hughes, T. P., Folke, C., Carpenter, S. R., \& Rockström, J. (2005). Social-Ecological Resilience to Coastal Disasters. Science, Vol. 309, Issue 5737, 1036-1039.

Ainuddin, S., P.Aldrich, D., K.Routray, J., ShabanaAinuddin, \& AbidaAchkazai. (2013). The need for local involvement: Decentralization of disaster management institutions in Baluchistan, Pakistan. International Journal of Disaster Risk Reduction, Volume 6, 50-58.

Athukorala, P.-c., \& Resosudarmo, B. P. (2006). The Indian Ocean Tsunami: Economic Impact, Disaster Management, and Lessons. Journals Resources About Contact, Volume 4, Issue 1, 318-339.

Careem, M. (2016). Sahana: Overview of a Disaster Management System. Geoscience and Remote Sensing Symposium, vol. 4 , $212-$ 2243.

Djalante, R., Thomalla, F., Sabaruddin, M., \& Carnegie, S. M. (2011). Building resilience to natural hazards in Indonesia: progress and challenges in implementing the Hyogo Framework for Action. Journal of ecosystem dynamics and local knowledge, 283-304.

Faulkner, B. (2001). Towards a framework for tourism disaster management. Tourism Management Volume 22, Issue 2, 135-147.

Gruyter, W. d. (2011). A Social Vulnerability Index for Disaster Management. Journal of Homeland Security and Emergency Management, Volume 8, Issue 1, 712-732.

Hewege, C. R., \& Perera, L. C. (2013). In Search of Alternative Research Methods in Marketing: Insights from Layder's Adaptive Theory Methodology. Contemporary Management Research, Vol. 9, No. 3, 343-360. 
Himayatullah, K., \& Abuturab, K. (2017). Natural hazards and disaster management in Pakistan. Natural hazards and disaster management in Pakistan, 14-45.

Hussain, F., \& Qasim, M. A. (2015). The Pakistani Equity Market in 50 Years: A Review. The Pakistan Development Review Vol. 36, No. 4, 863-872.

Hussain, I., \& Junaid, H. (2013). Floods Management Strategies in Pakistan. Journal for Tourism Development in Asia, 281-298.

Jemes, s. (2009). Knowledge model for post-disaster management. International Journal of Strategic Property Management, Vol. 13, issue. $2,117-128$.

Kapucu, N. (2015). Non-profit response to catastrophic disasters. Disaster Prevention and Management: An International Journal, Vol. 16 Issue: $4,551-561$.

Malik, \& H, C. (2016). Disaster Management in Pakistan, Volume 169 Issue 2. Proceedings of the Institution of Civil Engineers Municipal Engineer, 85-99.

Mansourian, A., Rajabifard, A., Zoeja, M., \& I.Williamson. (2006). Using SDI and web-based system to facilitate disaster management. Computers \& Geosciences, Volume 32, Issue 3, 303-315.

MateeulHaq, MemonAkhtarSher, MuhammadSiddiqi, Jillani, P., \& Rahmatullah. (2012). Techniques of Remote Sensing and GIS for flood monitoring and damage assessment: A case study of Sindh province, Pakistan. The Egyptian Journal of Remote Sensing and Space Science, Volume 15, Issue 2, 135-141.

Mete, H. O., \& B.Zabinsky, Z. (2010). Stochastic optimization of medical supply location and distribution in disaster management. International Journal of Production Economics, Volume 126, Issue 1, 76-84.

Moe, T. L., \& Pathranarakul, P. (2006). An integrated approach to natural disaster management: Public project management and its critical success factors. Disaster Prevention and Management: An International Journal, Vol. 15 Issue. 3, 396-413.

Molenberghs, G. (2015). Survey Methods \& Sampling Techniques. Interuniversity Institute for Biostatistics and statistical Bioinformatics, vol.3, 232-259.

Moore, J. (2005). Disaster management using an enhanced syndication platform. BiBTeX.

NezihAltay, \& G.Green, W. ( 2006). OR/MS research in disaster operations management. European Journal of Operational Research,Volume 175, Issue 1, 475-493.

O'Brien, G., O'Keefe, P., Gadema, Z., \& Swords, J. (2010). Approaching disaster management through social learning. Disaster Prevention and Management: An International Journal, Vol. 19 Issue: 4, Vol. 19 Issue: 4, 498-508.

Obwaya, R. E. (2010). Disaster Risk Reduction Strategies in Preparedness: A case study of Jomo Kenyatta International Airport (JKIA) Nairobi Kenya. University of the Free State.

Ottawa. (2003). Survey Methods and Practices. Canada: National Library of Canada.

Perry, R. W. (2003). Incident management systems in disaster management. Disaster Prevention and Management: An International Journal Vol. 12 Issue, 5, 405-412.

RehmanTariq, M. A., \& Giesen, N. d. (2012). Floods and flood management in Pakistan. Physics and Chemistry of the Earth, Volumes $47-48,11-20$.

Shaw, R., \& Goda, K. (2004). From Disaster to Sustainable Civil Society: The Kobe Experience. Disaster, Volume 28, Issue 1, $16-40$.

Shaw, R., Shiwaku, K., Kobayashi, H., \& Kobayashi, M. (2004). Linking experience, education, perception and earthquake preparedness. Disaster Prevention and Management: An International Journal, Vol. 13 Issue: 1, 39-49.

Stanganelli, M. (2008). A new pattern of risk management: The Hyogo Framework for Action and Italian practise. Socio-Economic Planning Sciences, Volume 42, Issue 2, 92-111.

Tingsanchali, T. (2012). Urban flood disaster management. Procedia Engineering, Volume 32, 25-37.

Trim, P. R. (2004). An integrative approach to disaster management and planning. Disaster Prevention and Management: An International Journal, Vol. 13 Issue: 3, 218-225.

UNDP. (2016). Disaster Risk Reduction in Pakistan. Pakistan: UNDP.

UNDP. (2005). Risk, Security and Disaster Management. Annual Review of Political Science, Vol. 8, 335-356.

Vasilescu, L., Khan, A., \& Khan, H. (2008). Disaster Management Cycle - A Theoretical Approach. Editura Universitaria Craiova, 43-50.

Williams, C. (2007). Research Methods. Journal of Business \& Economic Research, Volume 5, Number 3, 65-73.

Yusoff, R. M., \& Khan, F. (2013). Stress and Burnout in the Higher Education Sector in Pakistan:A Systematic Review of Literature. Research Journal of Recent Sciences, Vol. 2(11), 90-98.

ZubairAhmed. (2013). Disaster risks and disaster management policies and practices in Pakistan: A critical analysis of Disaster Management Act 2010 of Pakistan. International Journal of Disaster Risk Reduction, Volume 4, 15-20. 